\title{
Grade Eleven Students' Mathematics Beliefs about Contexts Support in West Arsi Zone, Ethiopia
}

\author{
Mulugeta Atnafu Ayele ( $\mathrm{PhD})$ (Corresponding author) \\ Dept. of Science \& Mathematics Education, Addis Ababa University \\ Addis Ababa, Ethiopia \\ E-mail: ayatmu@yahoo.com \\ Tesfu Belachew Dadi (PhD) \\ Dept. of Mathematics, Meda Wolabu University \\ Bale, Oromya, Ethiopia \\ E-mail: tesfu.belachew@yahoo.com
}

\author{
Received: March 13, 2017 Accepted: May 9, 2017 Published: May 12, 2017 \\ doi:10.5296/jse.v7i2.10935 URL: https://doi.org/10.5296/jse.v7i2.10935
}

\begin{abstract}
Students' beliefs in mathematics education play an important role in students' mathematics learning and achievement. Therefore, investigating students' mathematics beliefs about context supports are essential in educational research. Accordingly, the purpose of this research was to investigate students' mathematics beliefs about context support such as family context, social context, and school and classroom context about mathematics learning. To addressi this purpose, mixed-methods approach using a quantitative investigation followed by a qualitative investigation were employed. The participants were 545 students selected from four schools in West Arsi Zone using multistage sampling. The quantitative data obtained were analysed using percentage, mean, independent samples t-test, and ANOVA. The major findings were the students' beliefs about contexts support and its components such as students' beliefs about fathers', mothers', siblings', peers', teachers', textbooks' and schools' support in learning mathematics denoted as medium level, which is neither positive nor negative. Regarding students' beliefs about contexts support and its components, there were no significant differences with respect to gender; but there were significant differences with respect to achiever levels. In addition, there were significant differences between students' beliefs about mothers', fathers', and peers' support in learning mathematics in favor of students with parents are in urban; but no significant for others.
\end{abstract}


Keywords: Mathematics belief, Context support, Family support, Social support, School support 


\section{Introduction}

\subsection{Background of the Study}

In Ethiopia, mathematics is a prerequisite for admission into university and college areas of study. It is used as a language for science and technology (MoE, 1994). Indeed, the government of Ethiopia has recently designed a strategy through which $70 \%$ of the university enrollment would be in science and technology, which deserves strong mathematics knowledge (MoE, 2008). However, in Ethiopia, the challenge facing today is not only providing equitable access to its growing students population, but also to ensure that education is effective in supplying students with the necessary skills (e.g., mathematics problem solving skill) to fully contribute to the development of the society and the economy (NAE, 2010). To realize this it necessitates improving the effectiveness of the learning process which requires positive students' beliefs (Op't Eynde \& De Corte, 2003).

One of the students' belief components of in mathematics education is students' beliefs about the context support in mathematics education. It refers to students' views and perceptions about the support of family context, school and classroom context, and social context in learning mathematics. It is important to consider context in research related to students' beliefs in mathematics education (Diego-Mantecón, Andrews, Op’t Eynde \& González-López, 2007), since students will develop representations of the beliefs and purposes of the community of others in which they reside, and be influenced by these (Op't Eynde, De Corte, \& Verschaffel, 2002).

Indeed, the kinds of beliefs revealed within the given context influence students' beliefs in mathematics education in one way or the other. Negative mathematics talks from peers, parents, and teachers impact students' beliefs in mathematics education. The roles of families in fostering beliefs of their children are very crucial; for example, families played a great role in nurturing the self-beliefs of their children are very crucial (Pajares \& Schunk, 2002). Moreover, in the home in which families who themselves do not have positive beliefs in mathematics education can deliberately or not deliberately transfer such beliefs to their children. Because, in the context of doing mathematics, the emotions expressed by one will certainly and reciprocally shape the other within parent-child interactions (Else-Quest, Hyde, \& Hejmadi, 2008).

As a member of the context the impact of peers on students' beliefs in mathematics is also great; for example, social comparisons with peers are critical to the development of self-beliefs. Indeed, peers increased self-efficacy through modeling and persuasion, and potentially using group work brings about achievement (Oettingen, 1995).

Besides family and social factors, students' beliefs in mathematics education may have its roots in both school and classroom context, in which they are considered as a community in which children are expected to publicly express their thinking, and engage in mathematical practice characterized by conjectures, arguments and justifications (Cobb, Wood \& Yackel, 1993). Indeed, in classroom context, teachers have a remarkable influence on students' construction of their beliefs through the ways they present the subject matter, the kinds of 
task they set, assessment methods, procedures and criteria (Pehkonen, 1998; Törner 1998). Teacher's beliefs also play a critical role to choose and employ the instructional and assessment strategies as well as self-beliefs they foster with their students (Stipek, Givvin, Salmon, \& MacGyvers, 2001). Of course, careful instructional design could play a significant role in promoting students' beliefs. Teachers' beliefs about mathematics also play a major role in influencing their students' attitudes, self efficacy, interests and achievement (Tschannen-Moran \& Hoy, 2001). In another contribution Midgely, Feldlaufer, and Eccles (1989) found that mathematics teachers' beliefs in their efficacy to teach mathematics had an effect on their students. Students in the class of teachers with a positive sense of efficacy in teaching were more likely to believe that they were performing better in mathematics than students in the class of teachers with a lower sense of efficacy in teaching mathematics. Also, students of teachers with high efficacy believed mathematics to be less difficult than students of lower efficacy teachers. Overall, teachers' attitudes had a stronger relationship to the beliefs in mathematics of low-achieving students than to the beliefs in mathematics of high-achieving students (Kalder \& Lesik, 2011). In addition, when students, especially younger ones, are encouraged by teachers and find success in mathematics, their beliefs can drastically improve (Ma \& Xu, 2004).

Different material resources within the school and classroom contexts required for effective function have also their own impact on students' beliefs in mathematics education. Mediating artifacts, in student mathematics interaction, which include mathematics textbooks, digital technologies, as well as tasks and problems and language (Rezat \& Strässer, 2012) affects directly the nature of student learning, and then students' beliefs in mathematics education. For example, previous research shows that students found mathematics word problem solving difficult not because of poor mathematics skills but difficulty in understanding the text (Bernardo, 1999).

\subsection{Statement of the Problem}

Ethiopian secondary students' performance in mathematics is very low (Asfaw, Otore, Ayele, $\&$ Gebremariam, 2009; Atnafu, 2010; NAE, 2010). One of the reasons for this inadequacy is assumed to be the beliefs of students themselves (Asfaw, et al., 2009; Atnafu, 2010; NAE, 2010). Indeed, in Ethiopia, problem of mathematics concept understanding is widely observed in high school students' (Tuge, 2008). This problem is also associated with problem of students' beliefs in mathematics (Leder, Pehkonen, \& Torner, 2002). In addition, in recent years much concern has been expressed about students' reluctance to continue with the study of mathematics, science and technology beyond the compulsory years (Leder, Pehkonen, \& Törner, 2002; Semela, 2010). One of the effects for the low belief of students in mathematics may be due to students' mathematics beliefs about context support such as about the family context, school and classroom context, and social context about mathematics learning.

\subsection{Research Questions of the Study}

The purpose of this research was to investigate students' mathematics beliefs about context support. That is, it refers to the views about the family context (father, mother \& siblings supports), social context (peer support), and school and classroom context (mathematics teachers, textbook and school supports) about mathematics learning. In this study, the 
following research questions were posed to be addressed:

1) To what extent the students' beliefs about context support in learning mathematics?

2) Is there a significant difference in the students' beliefs about context support in learning mathematics with respect to gender?

3) Is there a significant difference in the students' beliefs about context support in learning mathematics with respect to parents' residence?

4) Is there a significant difference in the students' beliefs about context support in learning mathematics with respect to achiever level?

\section{Materials and Methods}

\subsection{Research Design}

In this research to recognize and describe the real appearance of students' beliefs about contexts support, and to explain the students lived experiences for the reflected students' beliefs about contexts support in mathematics education mixed-methods approach using a quantitative investigation for obtaining descriptive statistics followed by a qualitative investigation were employed. In this way, methods of collecting and analyzing data from the quantitative and the qualitative research approaches were incorporated in this study (Creswell, 2003). Accordingly, in phase one mathematics belief contexts support scale was applied to address the research questions of this study. Because, based on the research questions of this study, the mathematics belief contexts support scale used to address the views of large number of participants using many items. In phase two questionnaire, semi-structured interview, and focused group discussion were applied to address the rationales underlying students' belief contexts support in mathematics education depending on the quantitative results. These helped to gain insight into lived experiences of students on the reflected students' belief contexts support in mathematics education through understanding the experience of the individuals reflecting their beliefs. Moreover, they further helped to clarify the quantitative data. In doing so, the two phases of the research were occurred sequentially, where the qualitative data was used to explain the quantitative data. Hence, in this study explanatory sequential mixed methods design was employed (Creswell, 2014). It is considered explanatory because the initial quantitative data results are explained further with the qualitative data. It is considered sequential because the initial quantitative phase is followed by the qualitative phase.

\subsection{Population and Sampling Method}

All grade eleven students from government schools of West Arsi Zone, Oromia, Ethiopia, were constitute the population of the study. Multistage sampling was used to address the different geographic sites; difference in population size, the social and the cultural differences. Thus, from 11 preparatory schools four schools from West Arsi Zone were selected using cluster sampling. Hence, from grade 11, five sections from Shashemene preparatory school, four sections from Arsi Negele preparatory school, four sections from Dodola preparatory school, and three sections from Gedeb Hasasa preparatory school were selected using lottery 
method to collect data. The researcher then considered all students in the selected sections for data collection. The total number of the participant of the students were 545, where 325 (59.6\%) were male and $220(40.4 \%)$ were female; $307(56.3 \%)$ were urban area and 238 (43.7\%) were rural area; and $150(27.5 \%)$ were high achiever, 263 (48.3\%) were middle achiever and $132(24.2 \%)$ were lower achiever in mathematics. Also, for this study three students for interview and five students for focused group discussion were selected from each selected preparatory schools based on purposeful sampling.

\subsection{Instruments of Data Collection}

In order to investigate the students' belief about context support in learning mathematics, mathematics belief about context support scale was adapted from Hannula, Kaasila, Laine, \& Pehkonen (2005) and reviewed for this study. In this regard, 54 items covering the seven beliefs about context support components. The seven beliefs about context support in learning mathematics components were: students' beliefs about mothers' support, students' beliefs about fathers' support, students' beliefs about siblings' support, students' beliefs about peers' support, students' beliefs about mathematics teachers' support, students' beliefs about mathematics textbooks' support, and students' beliefs about schools' support in learning mathematics. In order to investigate the rationales underlying students' belief about context support in learning mathematics, semi structured interview and focused group discussion questions were developed based on the results of the quantitative data obtained using belief about context support in learning mathematics scale. Each of the semi-structured interview and focused group discussion has twelve questions. The purpose of the semi-structured interview and the focused group discussion questions served to see respondents' justification from multiple angles to reveal a better detailed evidence of the study.

\subsection{Validity and Reliability of the Instruments}

In this research, to maintain both the content and the face validity of the mathematics belief about context support scale, it was repeatedly commented and checked by colleagues and then by advisors. A pilot study was conducted to determine the validity and reliability of the scale. From Didea Preparatory School forty grade 11 students were selected for the pilot study, and the alpha coefficient of Cronbach yielded 0.780 for students' beliefs about mothers' support scale; 0.857 for students' beliefs about fathers' support scale; 0.864 for students' beliefs about siblings' support scale; 0.835 for students' beliefs about mathematics teachers' support scale; 0.814 for students' beliefs about peers' support scale; 0.724 for students' beliefs about mathematics textbooks' support scale; 0.820 for students' beliefs about schools' support scale; and 0.841 for students' beliefs about context support scale. The Cronbach Alpha Coefficients of reliability for this variable indicated that they have high internal consistency reliability.

\subsection{Methods of Data Analysis}

In accordance with the purpose of the study percentage, mean, independent samples t-test, one way ANOVA were employed in the study in order to investigate the students' beliefs about context support in mathematics education. All qualitative data collected through 
semi-structured interview and focused group discussion questions were coded and assigned the respondents opinion in certain categories, and classified the data based on themes.

\section{Results and Discussions}

\subsection{Results}

As the students' beliefs about context support in learning mathematics scale was a five point likert scale with values and the average ranged from 1.0 to 5.0. Thus, using the idea of Norouzian, and Mehdizadeh (2013) adapting their criteria to categorize variables as low, medium and high based on the range of scores given, students' beliefs about context support in learning mathematics such as high (strongly positive beliefs: 4.5 to 5.0 and positive belief: 3.5 to 4.4 ); medium (neutral: 2.5 to 3.4 ); and low (negative beliefs: 1.5 to 2.4 and strongly negative beliefs: 1.0 to 1.4$)$.

Below is the analysis of the first research question that was 'To what extent the students' beliefs about context supports in learning mathematics?' and analyzed using mean and percentage. Table 1 below shows the descriptive statistics and level's of the students' beliefs about context support in learning mathematics.

Table 1. The nature of students' beliefs about the contexts support in learning mathematics based on their mean scores

\begin{tabular}{lccccc}
\hline Belief Components & N & M & SD & Levels & $\begin{array}{c}\text { Description of } \\
\text { levels }\end{array}$ \\
\hline Students' beliefs about mothers' support & 545 & 3.36 & .99 & Medium & Neutral \\
Students' beliefs about fathers' support & 545 & 3.37 & 1.03 & Medium & Neutral \\
$\begin{array}{l}\text { Students' beliefs about siblings' support } \\
\text { Students' beliefs about peers' support }\end{array}$ & 545 & 2.99 & .97 & Medium & Neutral \\
$\begin{array}{l}\text { Students' beliefs about mathematics teachers' } \\
\quad \text { support }\end{array}$ & 545 & 3.16 & 1.07 & Medium & Neutral \\
$\begin{array}{l}\text { Students' beliefs about mathematics } \\
\quad \text { textbooks' support }\end{array}$ & 545 & 3.10 & .89 & Medium & Neutral \\
$\begin{array}{l}\text { Students' beliefs about schools' support } \\
\begin{array}{l}\text { Students' beliefs about contexts support in } \\
\quad \text { learning mathematics }\end{array}\end{array}$ & 545 & 2.89 & .93 & Medium & Neutral \\
\hline
\end{tabular}

Table 1 show that the nature of each of the components of students' beliefs about contexts support in learning mathematics denoted as medium level, which is neither positive nor negative. Indeed, the mean of students' beliefs about mathematics teachers' support in learning mathematics was the least from the students' beliefs about contexts support in learning mathematics components, and the mean of students' beliefs about fathers' support in learning mathematics was the highest. For the aggregate average of the components, the nature of students' beliefs about contexts support in learning mathematics denoted as medium level, which is neither positive nor negative.

From the above finding, however, all students did not have neutral beliefs on the context 
belief components. To see this consider Table 2 that reveals the percentage of respondents in each level based on average scores of the context components.

Table 2. Percentage of respondents in each level of students' beliefs about contexts support components in learning mathematics

\begin{tabular}{|c|c|c|c|c|c|c|}
\hline \multirow[t]{2}{*}{ Belief Components } & \multirow[t]{2}{*}{$\mathrm{N}$} & \multicolumn{5}{|c|}{ Percentage of Respondents } \\
\hline & & $\begin{array}{l}\text { Strongly } \\
\text { positive }\end{array}$ & Positive & Neutral & Negative & $\begin{array}{l}\text { Strongly } \\
\text { negative }\end{array}$ \\
\hline Students' beliefs about mothers' support & 545 & 16.7 & 34.1 & 27.2 & 21.3 & 0.7 \\
\hline Students' beliefs about fathers' support & 545 & 16.3 & 37.1 & 21.7 & 24.2 & 0.7 \\
\hline Students' beliefs about siblings' support & 545 & 7.0 & 32.3 & 18.0 & 42.8 & 0.0 \\
\hline Students' beliefs about peers' support & 545 & 12.8 & 33.8 & 21.3 & 29.7 & 2.4 \\
\hline $\begin{array}{l}\text { Students' beliefs about mathematics } \\
\text { teachers' support }\end{array}$ & 545 & 10.3 & 21.7 & 16.3 & 44.2 & 7.5 \\
\hline $\begin{array}{l}\text { Students' beliefs about mathematics } \\
\text { text's support }\end{array}$ & 545 & 1.1 & 42.6 & 22.0 & 34.1 & 0.2 \\
\hline Students' beliefs about school's support & 545 & 0.7 & 35.6 & 18.7 & 41.7 & 3.3 \\
\hline
\end{tabular}

From Table 2, it can be seen that all students are not assigned in the same neutral level of beliefs. Related to students' beliefs about family context such as mothers'; fathers' and siblings' supports there are only $27.2 \% ; 21.7 \%$; and $18.0 \%$ of students have neutral beliefs respectively; about $50.8 \% ; 53.4 \%$; and $33.0 \%$ of students have either strongly positive or positive beliefs respectively; and about $22.0 \%$; $24.9 \%$; and $42.8 \%$ of them have either negative or strongly negative beliefs respectively. Related to students' beliefs about social context such as peers' support there are only $21.3 \%$ of students have neutral beliefs; about $46.6 \%$ of students have either strongly positive or positive beliefs; where as $32.1 \%$ of them have either negative or strongly negative beliefs. Related to students' beliefs about school and classroom context such as mathematics teachers'; mathematics textbooks'; and schools' supports there are only $16.3 \% ; 22.0 \%$; and $18.7 \%$ of students have neutral beliefs respectively; about $32.0 \%$; $43.7 \%$; and $36.3 \%$ of students have either strongly positive or positive beliefs respectively; where as $51.7 \% ; 34.3 \%$; and $45.0 \%$ of them have either negative or strongly negative beliefs respectively.

Below is the analysis of the second research question that was 'Is there a significant difference in the students' beliefs about context support in learning mathematics with respect to gender?'

\subsubsection{Students' beliefs about context support with respect to gender}

In order to examine the significant differences of the students' beliefs about context support in learning mathematics with respect to gender, independent sample t-test was used. Table 3 below shows descriptive statistics and independent sample t-test for the students' beliefs about context support in learning mathematics with respect to gender. 
Table 3. The independent t-test for comparing male and female students' beliefs about context's support in learning mathematics

\begin{tabular}{|c|c|c|c|c|c|c|c|c|}
\hline Belief Components & Gender & $\mathrm{N}$ & $\mathrm{M}$ & SD & $\mathrm{SE}$ & df & $\mathrm{t}$ & $\mathrm{p}$ \\
\hline \multirow{3}{*}{$\begin{array}{l}\text { Students' beliefs about mothers' } \\
\text { support }\end{array}$} & & & & & & 543 & -1.33 & .185 \\
\hline & Male & 325 & 3.31 & .97 & .05 & & & \\
\hline & Female & 220 & 3.43 & 1.02 & .07 & & & \\
\hline \multirow{3}{*}{$\begin{array}{l}\text { Students' beliefs about fathers' } \\
\text { support }\end{array}$} & & & & & & 543 & -.27 & .787 \\
\hline & Male & 325 & 3.37 & 1.02 & .06 & & & \\
\hline & Female & 220 & 3.39 & 1.04 & .07 & & & \\
\hline \multirow{3}{*}{$\begin{array}{l}\text { Students' beliefs about siblings' } \\
\text { support }\end{array}$} & & & & & & 543 & 1.49 & .138 \\
\hline & Male & 325 & 3.04 & .95 & .05 & & & \\
\hline & Female & 220 & 2.91 & .98 & .07 & & & \\
\hline \multirow{3}{*}{$\begin{array}{l}\text { Students' beliefs about peers' } \\
\text { support }\end{array}$} & & & & & & 543 & -.37 & .710 \\
\hline & Male & 325 & 3.14 & 1.03 & .06 & & & \\
\hline & Female & 220 & 3.18 & 1.12 & .08 & & & \\
\hline \multirow{3}{*}{$\begin{array}{l}\text { Students' beliefs about } \\
\text { mathematics teachers' support }\end{array}$} & & & & & & 543 & .98 & .329 \\
\hline & Male & 325 & 2.75 & 1.19 & .07 & & & \\
\hline & Female & 220 & 2.65 & 1.12 & .08 & & & \\
\hline \multirow{3}{*}{$\begin{array}{l}\text { Students' beliefs about } \\
\text { mathematics textbooks' support }\end{array}$} & & & & & & 543 & .38 & .707 \\
\hline & Male & 325 & 3.11 & .89 & .05 & & & \\
\hline & Female & 220 & 3.08 & .90 & .06 & & & \\
\hline \multirow{3}{*}{$\begin{array}{l}\text { Students' beliefs about school's } \\
\text { support }\end{array}$} & & & & & & 543 & .87 & .385 \\
\hline & Male & 325 & 2.91 & .95 & .05 & & & \\
\hline & Female & 220 & 2.84 & .90 & .06 & & & \\
\hline \multirow{3}{*}{$\begin{array}{l}\text { Students' beliefs about Context's } \\
\text { support }\end{array}$} & & & & & & 543 & .218 & .828 \\
\hline & Male & 325 & 3.07 & .64 & .04 & & & \\
\hline & Female & 220 & 3.06 & .68 & .05 & & & \\
\hline
\end{tabular}

The findings from the independent $\mathrm{t}$-tests in Table 3, indicates that even though the means are unequal in all cases, there was no statistically significant difference between male and female students' beliefs about mothers' support, fathers' support, siblings' support, mathematics teachers' support, peers' support, mathematics textbooks' support, and schools' support in mathematics education, $t(543)=-1.33, t(543)=-.27, t(543)=1.49, t(543)=.98, t(543)=-.37$, $t(543)=.38, t(543)=.87, p>.05$ respectively. The aggregate in 'students' beliefs about context's support in learning mathematics' also indicates that even though the means are unequal there was no statistically significant difference $(t(543)=.218, p>.05)$ between male and female students' beliefs about context's support in mathematics education.

Below is the analysis of the third research question that was 'Is there a significant difference in the students' beliefs about context support in learning mathematics with respect to parents' residence?' 
3.1.2 Students' beliefs about context support with respect to parents' residence

Following the same principle above in testing parents' residence difference in students' beliefs about context support in learning mathematics, the independent sample t-test was also applied. Table 4 below shows descriptive statistics and independent sample t-test for the students' beliefs about context support in learning mathematics with respect to parents' residence.

Table 4. The independent t-test for comparing urban and rural students' beliefs about context's support in learning mathematics

\begin{tabular}{|c|c|c|c|c|c|c|c|c|}
\hline Belief Components & $\begin{array}{l}\text { Parents' } \\
\text { Residence }\end{array}$ & $\mathrm{N}$ & $\mathrm{M}$ & SD & $\mathrm{SE}$ & df & $\mathrm{t}$ & $\mathrm{p}$ \\
\hline \multirow{3}{*}{$\begin{array}{l}\text { Students' beliefs about mothers' } \\
\text { support }\end{array}$} & & & & & & 543 & 4.94 & .000 \\
\hline & Urban & 307 & 3.54 & 1.00 & .06 & & & \\
\hline & Rural & 238 & 3.13 & .94 & .06 & & & \\
\hline \multirow{3}{*}{$\begin{array}{l}\text { Students' beliefs about fathers' } \\
\text { support }\end{array}$} & & & & & & 543 & 2.38 & .018 \\
\hline & Urban & 307 & 3.47 & 1.01 & .06 & & & \\
\hline & Rural & 238 & 3.26 & 1.03 & .07 & & & \\
\hline \multirow{3}{*}{$\begin{array}{l}\text { Students' beliefs about siblings' } \\
\text { support }\end{array}$} & & & & & & 543 & -.90 & .370 \\
\hline & Urban & 307 & 2.96 & .96 & .05 & & & \\
\hline & Rural & 238 & 3.03 & .98 & .06 & & & \\
\hline \multirow{3}{*}{$\begin{array}{l}\text { Students' beliefs about peers' } \\
\text { support }\end{array}$} & & & & & & 543 & 4.39 & .000 \\
\hline & Urban & 307 & 3.33 & 1.09 & .06 & & & \\
\hline & Rural & 238 & 2.94 & 1.00 & .06 & & & \\
\hline \multirow{3}{*}{$\begin{array}{l}\text { Students' beliefs about } \\
\text { mathematics teachers' support }\end{array}$} & & & & & & 543 & 1.18 & .239 \\
\hline & Urban & 307 & 2.76 & 1.14 & .07 & & & \\
\hline & Rural & 238 & 2.64 & 1.19 & .08 & & & \\
\hline \multirow{3}{*}{$\begin{array}{l}\text { Students' beliefs about } \\
\text { mathematics textbooks' support }\end{array}$} & & & & & & 543 & .44 & .658 \\
\hline & Urban & 307 & 3.11 & .89 & .05 & & & \\
\hline & Rural & 238 & 3.08 & .90 & .06 & & & \\
\hline \multirow{3}{*}{$\begin{array}{l}\text { Students' beliefs about schools' } \\
\text { support }\end{array}$} & & & & & & 543 & 1.73 & .085 \\
\hline & Urban & 307 & 2.94 & .90 & .05 & & & \\
\hline & Rural & 238 & 2.80 & .97 & .06 & & & \\
\hline \multirow{3}{*}{$\begin{array}{l}\text { Students' beliefs } \\
\text { about context's support }\end{array}$} & & & & & & 543 & 2.95 & .003 \\
\hline & Urban & 307 & 3.13 & .65 & .04 & & & \\
\hline & Rural & 238 & 2.97 & .65 & .04 & & & \\
\hline
\end{tabular}

The findings from the independent t-tests in Table 4, shows that there were statistically significant differences between students' beliefs about: mothers', fathers', and peers' support 
in learning mathematics according to parents' residence, $t(543)=4.94, t(543)=2.38$, $t(543)=4.39, p<.05$ respectively, in favor of students with parents are in urban in all cases.

As it was revealed in focused group discussion, students whose parents are in urban easily communicate with students and teachers in their school; they are also free to share their academic difficulties for peers, besides their mathematics teachers in need of advice and support from them as compare to students whose parents' are in rural. The root of this communication skill difference between students, whose parents' are in urban and in rural, is their home context, in which in Ethiopian context the urban home context is more democratic and allows free communication for children as compare to the rural home context.

On the other hand, even though the means are unequal there were no statistically significant differences between students belief about: siblings', mathematics teachers', mathematics textbooks', and schools' support in learning mathematics according to parents' residence, $t(543)=-.90, t(543)=1.18, t(543)=.44, t(543)=1.73, p>.05$ respectively. In addition for the aggregate, the students' beliefs about context's support in learning mathematics, the mean for students' whose parents are in urban was significantly greater than the mean of students' whose parents are in rural $(t(543)=2.95, p<.05)$.

As it was underlined in the interview and focused group discussion instead of peers, that are more influential on students' whose parents are in urban, siblings are more influential on students whose parents are in rural. In connection with high school education, in Ethiopian context siblings whose parents are in rural often live together in urban far from their families to attend high school education. In this situation, the elders have many responsibilities to follow up and to help their brothers and sisters in every aspect, so that their association is strong. Whereas, students whose parents are in urban are living with their parents so that they have stronger association with their parents than siblings as compare to students whose parents are in rural.

Below is the analysis of the fourth research question that was 'Is there a significant difference in the students' beliefs about context support in learning mathematics with respect to achiever level?'

\subsubsection{Students' beliefs about context support with respect to achiever level}

Following the same principle above in testing achiever level difference in students' beliefs about context support in learning mathematics, the one-way ANOVA was also applied. Table 5 below shows descriptive statistics and one-way ANOVA for the students' beliefs about context support in learning mathematics with respect to achiever level. 


\section{Ml Macrothink}

Table 5. One-way ANOVA for comparing low, middle and higher achiever students' beliefs about context's support in learning mathematics

\begin{tabular}{|c|c|c|c|c|c|c|c|}
\hline Belief Components & Achiever Level & $\mathrm{N}$ & M & $\mathrm{SD}$ & $\mathrm{SE}$ & $\mathrm{F}$ & $\mathrm{p}$ \\
\hline \multirow{4}{*}{$\begin{array}{l}\text { Students' beliefs about } \\
\text { mothers' support }\end{array}$} & & & & & & 56.01 & .000 \\
\hline & High achiever & 150 & 3.89 & .92 & .08 & & \\
\hline & Middle achiever & 263 & 3.37 & .92 & .06 & & \\
\hline & Low achiever & 132 & 2.75 & .87 & .08 & & \\
\hline \multirow{4}{*}{$\begin{array}{l}\text { Students' beliefs about } \\
\text { fathers' support }\end{array}$} & & & & & & 83.88 & .000 \\
\hline & High achiever & 150 & 4.04 & .84 & .07 & & \\
\hline & Middle achiever & 263 & 3.36 & .95 & .06 & & \\
\hline & Low achiever & 132 & 2.66 & .85 & .07 & & \\
\hline \multirow{4}{*}{$\begin{array}{l}\text { Students' beliefs about } \\
\text { siblings' support }\end{array}$} & & & & & & 79.32 & .000 \\
\hline & High achiever & 150 & 3.66 & .86 & .07 & & \\
\hline & Middle achiever & 263 & 2.91 & .91 & .06 & & \\
\hline & Low achiever & 132 & 2.40 & .70 & .06 & & \\
\hline \multirow{4}{*}{$\begin{array}{l}\text { Students' beliefs about } \\
\text { peers' support }\end{array}$} & & & & & & 57.04 & .000 \\
\hline & High achiever & 150 & 3.76 & .91 & .07 & & \\
\hline & Middle achiever & 263 & 3.14 & 1.06 & .07 & & \\
\hline & Low achiever & 132 & 2.52 & .86 & .07 & & \\
\hline \multirow{4}{*}{$\begin{array}{l}\text { Students' beliefs about } \\
\text { mathematics teachers } \\
\text { support }\end{array}$} & & & & & & 90.96 & .000 \\
\hline & High achiever & 150 & 3.57 & 1.09 & .09 & & \\
\hline & Middle achiever & 263 & 2.59 & 1.09 & .07 & & \\
\hline & Low achiever & 132 & 1.97 & .69 & .06 & & \\
\hline \multirow{4}{*}{$\begin{array}{l}\text { Students' beliefs about } \\
\text { mathematics text's } \\
\text { support }\end{array}$} & & & & & & 79.25 & .000 \\
\hline & High achiever & 150 & 3.65 & .70 & .06 & & \\
\hline & Middle achiever & 263 & 3.10 & .90 & .06 & & \\
\hline & Low achiever & 132 & 2.47 & .63 & .05 & & \\
\hline \multirow{4}{*}{$\begin{array}{l}\text { Students' beliefs about } \\
\text { school's support }\end{array}$} & & & & & & 113.72 & .000 \\
\hline & High achiever & 150 & 3.62 & .65 & .05 & & \\
\hline & Middle achiever & 263 & 2.79 & .92 & .06 & & \\
\hline & Low achiever & 132 & 2.23 & .59 & .05 & & \\
\hline \multirow{4}{*}{$\begin{array}{l}\text { Students' beliefs about } \\
\text { context's support }\end{array}$} & & & & & & 154.83 & .000 \\
\hline & High achiever & 150 & 3.61 & .49 & .04 & & \\
\hline & Middle achiever & 263 & 3.02 & .57 & .03 & & \\
\hline & Low achiever & 132 & 2.53 & .44 & .04 & & \\
\hline
\end{tabular}

From Table 5, it can be seen that the means of students' beliefs about: mothers', fathers', siblings', mathematics teachers', peers', mathematics textbooks', schools' supports and students' beliefs about context's support in learning mathematics showed statistical significant differences according to achiever level, $F(2,542)=56.01, F(2,542)=83.88$, 
$F(2,542)=79.32, \quad F(2,542)=90.96, \quad F(2,542)=57.04, \quad F(2,542)=79.25, \quad F(2,542)=113.72$, $F(2,542)=154.83, p<.05$ respectively according to achiever level variable amongst high, middle and low achiever students.

Since the students' beliefs about context's support and its components in learning mathematics had a significant difference with respect to achiever level, then the next question was which of the achiever levels made more significant difference. To find these paired comparisons Tukey HSD test was used. The Tukey HSD test for the paired achiever levels for students' beliefs about context's support and its components in learning mathematics is given by table 6 .

Table 6. Post Hoc tests for multiple comparisons of achiever level's on students' beliefs about context's support in teaching mathematics using Games-Howell

\begin{tabular}{|c|c|c|c|c|c|}
\hline Belief Components & $\begin{array}{l}\text { (I) Achiever } \\
\text { Level }\end{array}$ & $\begin{array}{c}\text { (J) Achiever } \\
\text { Level }\end{array}$ & $\begin{array}{c}\text { Mean } \\
\text { Difference(I-J) }\end{array}$ & $\mathrm{SE}$ & $\mathrm{p}$ \\
\hline \multirow{3}{*}{$\begin{array}{l}\text { Students' beliefs about } \\
\text { Fathers' support }\end{array}$} & High achiever & Middle achiever & .69 & .09 & .000 \\
\hline & & Low achiever & 1.39 & .10 & .000 \\
\hline & Middle achiever & Low achiever & .70 & .09 & .000 \\
\hline \multirow{3}{*}{$\begin{array}{l}\text { Students' beliefs about } \\
\text { mothers' support }\end{array}$} & High achiever & Middle achiever & .53 & .09 & .000 \\
\hline & & Low achiever & 1.15 & .11 & .000 \\
\hline & Middle achiever & Low achiever & .62 & .10 & .000 \\
\hline \multirow{3}{*}{$\begin{array}{l}\text { Students' beliefs about } \\
\text { siblings' support }\end{array}$} & High achiever & Middle achiever & .75 & .09 & .000 \\
\hline & & Low achiever & 1.26 & .09 & .000 \\
\hline & Middle achiever & Low achiever & .51 & .08 & .000 \\
\hline \multirow{3}{*}{$\begin{array}{l}\text { Students' beliefs about } \\
\text { peers' support }\end{array}$} & High achiever & Middle achiever & .63 & .10 & .000 \\
\hline & & Low achiever & 1.24 & .11 & .000 \\
\hline & Middle achiever & Low achiever & .61 & .10 & .000 \\
\hline \multirow{3}{*}{$\begin{array}{l}\text { Students' beliefs about } \\
\text { mathematics teachers' } \\
\text { support }\end{array}$} & High achiever & Middle achiever & .98 & .11 & .000 \\
\hline & & Low achiever & 1.59 & .11 & .000 \\
\hline & Middle achiever & Low achiever & .61 & .09 & .000 \\
\hline \multirow{3}{*}{$\begin{array}{l}\text { Students' beliefs about } \\
\text { mathematics textbooks' } \\
\text { support }\end{array}$} & High achiever & Middle achiever & .56 & .08 & .000 \\
\hline & & Low achiever & 1.18 & .08 & .000 \\
\hline & Middle achiever & Low achiever & .63 & .08 & .000 \\
\hline \multirow{3}{*}{$\begin{array}{l}\text { Students' beliefs about } \\
\text { schools' support }\end{array}$} & High achiever & Middle achiever & .83 & .08 & .000 \\
\hline & & Low achiever & 1.39 & .07 & .000 \\
\hline & Middle achiever & Low achiever & .56 & .08 & .000 \\
\hline \multirow{3}{*}{$\begin{array}{l}\text { Students' beliefs about } \\
\text { context's support }\end{array}$} & High achiever & Middle achiever & .60 & .05 & .000 \\
\hline & & Low achiever & 1.09 & .06 & .000 \\
\hline & Middle achiever & Low achiever & .49 & .05 & .000 \\
\hline
\end{tabular}


From Table 6, it can be seen that there was statistically significant difference between high achiever and middle achiever, high achiever and low achiever, and middle achiever and low achiever students' beliefs about: fathers', siblings', mathematics teachers', peers', mathematics textbooks', and schools' supports, and students' beliefs about context's support in learning mathematics $(p<.05)$. Also, from this table, the mean of high achiever students' beliefs about: fathers', siblings', mathematics teachers', peers', mathematics textbooks', and school's supports in learning mathematics were greater than the mean of both middle achiever and low achiever students'. This is due to the belief difference revealed in the belief items contained in students' beliefs about: fathers', siblings', mathematics teachers', peers', mathematics textbooks', and schools' support in learning mathematics.

This was supported by interview and focused group discussions results, because high achiever students believed that their mother, fathers, siblings, mathematics teachers, and peers have told them about the importance of mathematics, and encouraged them to study mathematics well more than both middle and low achiever students. Also, high achiever students believed that the contribution of their mothers, fathers, siblings, mathematics teachers, and peers on their motivation and result was relatively great as compare to both middle and low achiever students. As it was revealed in the interview, in particular, high achiever students believed that fathers' support in learning mathematics was great. Moreover, high achiever students believed that grade 11 mathematics text book have inspired their desire to study the textbook, have helped them to learn the subject by themselves and to understand it easily more than both middle and low achiever students. In contrast, as it was revealed in the interview and focused group discussion, the low achievers found that mothers', fathers', siblings', mathematics teachers', peers', mathematics textbooks', and schools' supports in learning mathematics was very low. In particular, the low achievers believed that mathematics teachers' support was inclined to only one direction, that is, it was high achievers oriented. Furthermore, low achiever students believe that grade 11 mathematics text book have not inspired their desire to study the text, have not helped them to learn the subject by themselves and to understand it easily. On other hand, the middle achiever students found that mothers', fathers', siblings', mathematics teachers', peers', mathematics textbooks', and schools' supports in learning mathematics were not satisfactory.

\subsection{Discussions}

The finding of this study raveled that the students' beliefs about contexts support and its components such as students' beliefs about fathers', mothers', siblings', peers', teachers', textbooks' and schools' support in learning mathematics denoted as medium level, which is neither positive nor negative. This is not consistent with Jin, et al. (2010), which they conducted a comparison study on high school students' mathematics belief systems between Han and Chaoxian Nationality and found strong students' beliefs in the area of learning contexts (Jin, et al., 2010).

Comparing with respect to gender, there were no statistically significant differences between male and female students' beliefs about context's support in mathematics education. In terms of parents' residence, there were statistically significant differences between students' beliefs 
about mothers', fathers', and peers' support in learning mathematics in favor of urban students. Interestingly, one possible explanation for statistically significant differences between students' beliefs about peers support in learning mathematics according to parents' residence was due to the communication skill of students whose parents are in urban than students whose parents are in rural. But there were no statistically significant differences between students belief about: siblings', mathematics teachers', mathematics textbooks', and schools' support in learning mathematics according to parents' residence. In connection with high school education, in Ethiopian context siblings whose parents are in rural often live together in urban far from their families to attend high school education. In this situation, the elders have many responsibilities to follow up and to help their brothers and sisters in every aspect, so that their association is strong. Whereas, students whose parents are in urban are living with their parents so that they have stronger association with their parents than siblings as compare to students whose parents are in rural. In general, there was statistically significant difference between students' beliefs about context's support in learning mathematics according to parents' residence. This was mainly due to the role and support of mothers, fathers, and peers, in which their contributions are more influential on every day mathematics activities on students whose parents are in urban than students whose parents are in rural. In terms of achiever level comparison, there were statistically significant difference between high achiever and middle achiever, high achiever and low achiever, and middle achiever and low achiever students' beliefs about context support and components of context support in learning mathematics.

There are many reasons for students' negative beliefs in mathematics education. The underlying reasons identified in this research are: insufficient supports from parents; inappropriate supports from mathematics teachers; and insufficient supports from the school.

Regarding the insufficient parents' supports, parents send their children to school within the context of getting a good job afterwards to be able to support them because of their low economic status. At the same time these parents anticipate their children to participate in different jobs so as to assist them financially. Especially in rural areas, parents believe that it would be more economical for their children to go farming than continue with the school and delaying earning a living. Moreover, these parents do not support their children when their children go a long distance for attending high school education, which is not available in the nearby village. Therefore, these students are often suffering from lack of both money and parents' moral support; and this contradict with Pajares \& Schunk (2002) stated families played a great role in nurturing the self-beliefs of their children are very crucial. In addition, most parents do not have the culture to talk with their children on their children's educational status, and even do not see their children's result at the end of the academic year. Because, shaping the children's belief in doing mathematics it is important about the parent-child interactions (Else-Quest, Hyde, \& Hejmadi, 2008). They also do not have bright hope and bright vision for their children's education. This may be due to the fact that many of them do not taste properly the fruits of education in their day today life. Hence, parents should not send their children because of both internal and external pressures, for example, for the sake 
of to be equal with their neighbours by sending their children to school. Instead, parents have to accept the importance of their children's education. Indeed, parents have to know that their persuasion, follow up, and supports with necessary resources are very influential in their children's education. Also, it is very important to remove parents responses, such as 'Don't worry, I have never understood fractions' or 'Never mind, maths was always tricky for me at school too', which plants a seed that may grow into a strong belief for children that they are incapable of learning mathematics (Whyte \& Anthony, 2012).

For the inappropriate mathematics teachers' support, most students' in the negative belief category believed that the contributions of mathematics teachers for students to have positive beliefs in mathematics education are very low. Indeed, students indicated that in one hand, mathematics teachers declare to them that mathematics is very essential; on other hand, they advertise that mathematics is difficult all the time, and the possibility that many students may not be successful in it. These teachers' massages in turn confused them so that to waver between perseverance and vacillation. The findings are in line with Stipek, Givvin, Salmon, \& MacGyvers (2001) stated that teacher's beliefs also play a critical role in which instructional and assessment strategies they choose to employ as well as in which self-beliefs they foster with their students.

Moreover, students explained that inappropriate services from their teachers, which include teachers' partiality, lack of consideration, and using exams as punishment stick, contributed for their negative beliefs in mathematics education. In this research students consider partiality as latent teachers discrimination related to achiever level, gender, and stream. Accordingly, most of the students in the negative belief category believed that mathematics teachers favour high achiever students; female students believed that mathematics teachers' fevour male students, and social science students believed that both the school and the mathematics teachers favour natural science students. The same sentiment also shared by many of the students in the neutral belief category. Also, teachers' lack of consideration for the students contribute for students' negative beliefs in mathematics education. Students need teachers that are patient and that choose a teaching method that addresses students with different learning styles, and achiever levels. However, mathematics teachers are rushing so that to cover the contents within the text book without giving the proper attention for students needs as it revealed by many students in this study. This teachers' characteristic observed in this research is similar to the result in Xiao, et al. (2009), in which teachers were merely focused on finishing the content which would appear in the standard examination. In addition, using exams as punishment stick is one of the reasons indicated by the students for their negative beliefs in mathematics education. Even, there were students in this research who have expelled from the class and made to miss the tests given by the teacher intentionally to hurt them.

According to the insufficient supports from the school, many students indicated that there were no adequate services from their school. For example, there was no well established and well equipped library with the necessary supplementary materials in their schools; there was no supplementary mathematics teaching. Even, students underlined that there were no satisfactory activities carried out by the schools to make them aware the importance and the 
usefulness of mathematics. In addition, students in particular from both negative and neutral belief categories believe that learning mathematics in English language have impacted their concept understanding and their beliefs in mathematics education. In line with these, the research of Rezat \& Strässer (2012) discussed that mathematics textbooks, digital technologies, as well as tasks and problems and language affect directly the nature of student learning, and then students' beliefs in mathematics education.

\section{Conclusions and Recommendations}

\subsection{Conclusions}

The purpose of this research was to investigate students' mathematics beliefs about contexts support. That is, it refers to the views about the family context (father, mother \& siblings supports), social context (peer support), and school and classroom context (mathematics teachers, textbook and school supports) about mathematics learning. The finding indicated that the students' beliefs about contexts support and its components such as students' beliefs about fathers', mothers', siblings', peers', teachers', textbooks' and schools' support in learning mathematics denoted as medium level, which is neither positive nor negative. Comparing with respect to gender, there were no statistically significant differences between male and female students' beliefs about mothers' support, fathers' support, siblings' support, mathematics teachers' support, peers' support, mathematics textbooks' support, schools' support, and students' beliefs about context's support in mathematics education. Regarding parents' residence, there were statistically significant differences between students' beliefs about mothers', fathers', and peers' support in learning mathematics in favor of students with parents are in urban in all cases; but there were no statistically significant differences between students belief about: siblings', mathematics teachers', mathematics textbooks', and schools' support in learning mathematics according to parents' residence. In general, there was statistically significant difference between students' beliefs about context's support in learning mathematics according to parents' residence. In terms of achiever level, there were statistically significant difference between high achiever and middle achiever, high achiever and low achiever, and middle achiever and low achiever students' beliefs about: fathers', siblings', mathematics teachers', peers', mathematics textbooks', and schools' supports, and students' beliefs about context's support in learning mathematics.

\subsection{Recommendations}

In this study, students indicated that insufficient support from parents, mathematics teachers, school contributed a lot for their negative and neutral beliefs in mathematics education. Hence, the following are recommended:

- Parents create awareness on the importance of mathematics achievement so that their children to devote their time and effort to academic activities starting from lower grades.

- Parents should motivate their children to study hard mathematics at home; and prepare rewards as reinforcement for the good performance of their children in mathematics.

- Parents provide their children with the necessary educational resources. 


\section{Macrothink}

- Mathematics teachers should be free from the spirit of partiality, so that to treat equally males and females, all achiever levels, students' with different ages, students' whose families in urban and in rural, students' with different ethnic groups, etc.

- Mathematics teachers show their students love, compassion and politeness; and create smooth relationship with their students.

- The curriculum developers balance the degrees of complexity of the contents in the text book and students capability at each class level. The text book should not to be crowded with many topics that are difficult to cover within the academic year.

- Schools create awareness about the importance and the usefulness of mathematics, in particular its usefulness in their education and its application in science, engineering, and technology.

- Schools perform a continuous counseling so that students to feel safe and comfortable, to build the culture of working hard and good time management, and the habit of helping each other.

- Schools break the trend of teacher dominated instruction so that students to get enough opportunities to dig by themselves, to snow, to harvest, and to see their seeds.

- Schools provide the students with the necessary resources, such as library that is well equipped with necessary reading materials, computers, and internet services. It is also important to establish and to strength mathematics club within the school.

\section{References}

Asfaw, E., Otore, D., Ayele, T., \& Gebremariam, Z. (2009). Science and mathematics secondary education. An Option paper presented at the Technical Workshop on Science and Mathematics Secondary Education in Africa (SEIA) Follow-up Program.

Atnafu, M. (2010). Relation between Tenth Grade Students' Attitude and Components of Attitude in Algebra with Algebra Achievement of Addis Ababa Secondary Schools.

Bernardo, A. B. I. (1999). Overcoming Obstacles to Understanding and Solving Word Problems in Mathematics. Educational Psychology, 19(2), 149-163. https://doi.org/10.1080/0144341990190203

Cobb, P., Wood, T. \& Yackel, E. (1993). Discourse, mathematical thinking, and classroom practice, in Contexts for Learning: Sociocultural Dynamics in Children's Development, E. Forman, N. Minick, and C. Stone, eds., Oxford University Press, New York, pp. 77-119.

Creswell, J. W. (2014). Research Design: Quantitative, Qualitative, and Mixed Methods (4 th ed.). Thousand Oaks, CA: Sage Publication.

Creswell, J. W. (2003). Research design: Qualitative, quantitative, and mixed methods approaches (2nd ed.). Thousand Oaks, CA: Sage.

Diego-Mantecón, J., Andrews, P., Op't Eynde, P., \& González-López, M. J. (2007). Assessing 
the structure and sensitivity of the beliefs systems yielded by the revised mathematics-related beliefs questionnaire. In DKüchemann (Ed.), Proceedings of the British Society for Research into Learning Mathematics, 27(3): 31-36. British Society for Research into Learning Mathematics. Retrived from:http://www.bsrlm.org.uk/IPs/ip27-3/BSRLM-IP-27-3-06.pdfm on $20 / 1 / 2014$.

Else-Quest, N. M., Hyde, J. S., \& Linn, C. (2008). Cross-national patterns of gender differences in mathematics: A meta-analysis. Psychological Bulletin, 136(1), 103-127. https://doi.org/10.1037/a0018053

Hannula, M. S., Kaasila, R., Laine, A., \& Pehkonen, E. (2005). The structure of student teacher's view of mathematics at the beginning of their studies. In Proceedings of the Fourth Congress of the European Society for Research in Mathematics Education. Sant Feliu de Guíxols, Spain-17-21 February (pp. 205-214).

Jin, M., Feng, X., Liu, J., \& Dai, F. (2010). Comparison study on high school students' mathematics belief systems between Han and Chaoxian nationality. Journal of Mathematics Education, 3(1), 138-151.

Kalder, R. S., \& Lesik, S. A. (2011). A Classification of Attitudes and Beliefs towards Mathematics for Secondary Mathematics Pre-Service Teachers and Elementary Pre-Service Teachers: An Exploratory Study Using Latent Class Analysis. Issues in the Undergraduate Mathematics Preparation of School Teachers, 5.

Leder, G. C., Pehkonen, E., \& Törner, G. (2002). Beliefs: A Hidden Variable in Mathematics Education? Kluwer Academic Publishers, 1-10. https://doi.org/10.1007/0-306-47958-3

Ma, X., \& Xu, J. (2004). The causal ordering of mathematics anxiety and mathematics achievement: A Longitudinal panel analysis. Journal of Adolescence, 27(2), 165-179.

Midgely, C., Feldlaufer, H., \& Eccles, J. (1989). Change in teacher efficacy and student selfand task-related beliefs in mathematics during the transition to junior high school. Journal of Educational Psychology, 81, 247-258. https://doi.org/10.1037/0022-0663.81.2.247

MoE. (2008). Annual Intake and Enrolment Growths and Professional and Programme Mix of Ethiopian Public Higher Education: Strategy and Conversion Plan, 2001-2005. Addis Ababa.

MoE. (1994). Education Sector Strategy. Addis Ababa: EMPDA

NAE. (2010). Ethiopian Baseline National Learning Assessment of Grades 10 \& 12 Students. Addis Ababa: NOE/MOE

Norouzian, R., \& Mehdizadeh, M. (2013). Reading Strategy Repertoires in EAP Contexts: Students and Teachers in Academic Reading Strategy Use. The International Journal of Language Learning and Applied Linguistics World, 5.

Oettingen, G. (1995). Cross-cultural perspectives on self-efficacy. In A. Bandura (Ed.), Self-efficacy in Changing Societies (pp. 149-176). New York: Cambridge University Press. https://doi.org/10.1017/CBO9780511527692.007 
Op 't Eynde, P. \& De Corte, E. (2003). Students' mathematics-related belief systems: Design and analysis of a questionnaire. Annual Meeting of the American Educational Research Association, April 21-25, Chicago.

Op't Eynde, P., De Corte, E., \& Verschaffel, L. (2002). Framing students' mathematics-related beliefs: A quest for conceptual clarity and a comprehensive categorization. In G. C. Leder, E. Pehkonen, \& G. Törner (Eds.), Beliefs: A Hidden Variable in Mathematics Education? Kluwer Academic Publishers, 13-37.

Pajares, F., \& Schunk, D. (2002). Self and self-belief in psychology and education: An historical perspective. In Improving academic achievement: Impact of psychological factors on education (Educational Psychology Series), ed. J. Aronson. New York, NY: Academic Press. https://doi.org/10.1016/B978-012064455-1/50004-X

Pehkonen, E. (1998). Teachers' conceptions on Mathematics Teaching. In M. Hannula (Ed.), Current state of research on mathematical beliefs V: Proceedings of the MAVI-5 workshop, August 22-25, 1997 (pp. 58-65). Helsinki, Finland: Department of Teacher Education, University of Helsinki.

Rezat, S. \& Strässer, R. (2012). From the didactical triangle to the socio-didactical tetrahedron: artifacts as fundamental constituents of the didactical situation. ZDM - The International Journal on Mathematics Education, 44, 641-651.

Semela, T. (2010). Who is joining physics and why? Factors influencing the choice of physics among Ethiopian university students. International Journal of Environmental \& Science Education, 5(3), 319-340.

Stipek, D., Givvin, K., Salmon, J., \& MacGyvers, V. (2001). Teachers' beliefs and practices related to mathematics instruction. Teaching and Teacher Education, 17(2), 213-226. https://doi.org/10.1016/S0742-051X(00)00052-4

Törner, G. (1998). Mathematical beliefs and their impact on the students' mathematical performance: Questions raised by the TIMSS results. In M. Hannula (Ed.), Current state of research on mathematical beliefs V: Proceedings of the MAVI-5 workshop, August 22-25, 1997 (pp. 83-91). Helsinki: Department of Teacher Education, University of Helsinki.

Tschannenn-Moran, M., \& Hoy, W. A. (2001). Teacher-Efficacy: Capturing an Elusive Construct. Teaching and Teacher Education, 17, 783-805. https://doi.org/10.1016/S0742-051X(01)00036-1

Tuge, T. (2008). Mathematics Curriculum, the Philosophy. Chernet Tuge. REVIEW ARTICLE, 4(1). Retrieved 14/2/ 2011 from http://www.ajol.info/index.php/ejesc/article/viewFile/42996/26552.

Whyte, J., \& Anthony, G. (2012). Maths anxiety: The fear factor in the mathematics classroom. New Zealand Journal of Teachers' Work, 9(1), 6-15.

Xiao, C., Yu, P., \& Yan, L. (2009). Influences on affect and achievement: high school students' epistemological beliefs about mathematics. Journal of Mathematics Education, 2(2), 1-11.p 